\title{
INFLUENCE OF IRRIGATION INTERVALS AND ANTITRANSPIRANTS ON GROWTH, YIELD AND QUALITY OF STRAWBERRY UNDER DRIP IRRIGATION SYSTEM B-PLANT MINERAL CONTENTS, WATER USE EFFICIENCY AND SCANNING ELECTRON MICROSCOPE OF STOMATA
}

\author{
Shadia A. Ismail ${ }^{(1)}$ and M. M. Mubarak ${ }^{(2)}$ \\ (1) Potato and Vegetatively Propagated Vegetable Crops Dept. Res. Hort. Res. Inst. ARC, Giza, \\ Egypt. \\ (2) Soil science Dep., Fac. of Agric., Ain Shams Uni., Cairo Egypt.
}

Received: May 28, 2016

Accepted : Jun. 26,2016

\begin{abstract}
This study was carried out at El-Kanater Horticulture Research Station, ElKaluobia Governorate during the two successive seasons of 20132014 and 20142015 to illustrate the effect of three irrigation intervals (each two, three, and four days) and five antitranspirants (potassium, sodium, and aluminum silicate, magnesium and calcium carbonate in addition to control on minerals content, water use efficiency and stomata morphology of Festival strawberry cultivar. The experimental design was split plot design with three replications under drip irrigation system .Results indicate that minerals contents of plant leaves as nitrogen, sodium and iron were affected with spacing water intervals in the two seasons while, magnesium and silicon were affected in the first season only. But each of potassium, calcium, zinc and manganese were not significantly affected with irrigation intervals. The best treatments resulted in the highest minerals content with irrigation each three or four days and foliar spray of kaolin or potassium silicate. The interaction treatments between irrigation intervals each four days and foliar spray of each kaolin and magnesium carbonate resulted in the highest values of water use efficiency compared to the other treatments in the two tested seasons. Results of scanning electron microscope analysis show that use of any of antitranspirants under study improved water status of the plant and reduced water loss through transpiration, as a result of the partial and relatively closure of the leaves stomata compared to the untreated plants. The study recommend irrigating strawberry plants each three days and foliar spray with each kaolin or magnesium carbonate, calcium carbonate, potassium silicate and sodium silicate respectively to increase minerals content, water use efficiency, and therefore, yield and quality of strawberry under Kalubia Governorate conditions.
\end{abstract}

Key wards: Strawberry, irrigation intervals antitranspirants. element contents ,water use efficiency and SEM of stomata.

\section{INTRODUCTION}

Strawberry ( Fragaria $x$ ananasa) plants are highly susceptible to drought conditions.In recent years water availability is one of the major problems in agriculture at a global scale and particular in Egypt, because of the shortage of available water resources. Strawberry plant is classified as a silicon non - accumulator. Yasuto and Takahashi (1986) reported that $\mathrm{SiO}_{2}$ content in dry leaves of strawberry increased with the duration of the reproductive growth stage at the beginning and the end of the flowering stage. Leaf area can also be restricted under drought stress to get a balance among water status of crop tissue and absorbed water by roots (Passioura 1996) No difference in response to the $K$ or $\mathrm{Na}$ salts of $\mathrm{Si}$ during the growth stages of strawberry plants and increased plant 
growth when treated with potassium and sodium silicate (Wang and Galletta 1996) on strawberry they showed that $\mathrm{Si},$. Macro and microelements concentration and their uptake were increased with increasing water supply to the soil in potato plants( Abd ElRheem , 2003).

Improvement of fruit quality and the potential use of antitranspirants is not restricted to water conservation but includes the maintenance of favorable water balance in plants, particularly at critical growth stages when high water potentials are essential for optimum plant growth (Saleh and El-Ashry, 2006). Ezzat et. al., (2009) indicated that foliar application of kaolin under low quantity of water increase macro and microelements in potato tubers compared to untreated plants.Also,they concluded that treated potato plants with kaolin increased leaf resistance to diffusion of water vapor Application of antitranspirants on sweet pepper reduced the fruit firmness in high $\mathrm{Mg} / \mathrm{Ca}$ and control also high $\mathrm{K}$ or high $\mathrm{Mg}$ significantly reduced $\mathrm{Ca}$ concentration ( Francisco and .Jose 2009). $\mathrm{K}, \mathrm{Ca}, \mathrm{Mg}$, and $\mathrm{Na}$ concentrations were measured under different deficit irrigation in leaves. leaf $\mathrm{Ca}$ content increased with decreasing water availability. No significant difference in $\mathrm{K}$ and $\mathrm{Mg}$ content was found while $\mathrm{Ca}$ content decreased in both deficit irrigation treatments. On the other hand, $\mathrm{Na}$ content tended to increase with deceasing soil water availability (Jensen 2011).Recently , Ahmed (2014) reported that spraying with ,kaolin or calcium carbonate on banana plants had positive effects to preventing the adverse effects of water stress as well as promoting yield and fruit quality. Moreover, he indicates that treated plants produced the maximum values of $\mathrm{N}, \mathrm{P}$ and $\mathrm{K}$ concentrations in the leaves compared to the untreated plants. In addition , application of antitranspirants has beneficial effects on $\mathrm{N}, \mathrm{P}, \mathrm{K}, \mathrm{Mg}, \mathrm{Zn}$ and $\mathrm{Fe}$ accumulation in the fruit and these elements are important for fruit quality (ElKhawaga and Mansour, 2014). Recently,ElZohiri and Abd El-Aal (2014) improved plant growth of taro by using magnesium carbonate as antitranspirants under different irrigation levels. Also, they indicated that magnesium carbonate as antitranspirant supported plants to absorb $\mathrm{N}$ and $\mathrm{Mg}$ and increased crop water use efficiency .

Antitranspirants are frequently classified into three categories. The first are reflective materials designed to reduce the amount of radiant energy absorbed, thus lowering the transpiration rate. The second category includes chemical compounds which affect guard cell metabolism causing the stomata to close and the third category are the filmforming and silicone antitranspirants which create a hydrophobic barrier that restricts the diffusion of water vapor from the leaf (Anderson and Kreith ,1978 and Lipe and Wendt , 2008).When stomata are opened $\mathrm{CO} 2$ is taken up while water is transpired. When stomata are closed little $\mathrm{CO} 2$ is taken up and the transpiration is lowered. By opening and closing the stomata plants can regulate the amount of water lost, by sacrificing $\mathrm{CO} 2$ uptake, when the environment condition are unfavorable (Farooq et. al., 2009) .

Reducing quantities of transpiration by application of antitranspirants is a very attractive subject in agriculture as it could save considerable quantities of water and also reduce plant stress caused by water deficits. However, the application of such film-forming materials has been related to the inhibition of the diffusion of carbon dioxide (CO2) more than of $\mathrm{H}_{2} \mathrm{O}$, resulting in a decrease in growth (Brown and Rosenberg, 1973) .Ahmet et. al., (2004) reported that increasing irrigation frequency caused significant increases in plant water consumption and yield, whereas, an excessive irrigation level had a negative 
effect on irrigation use efficiency on summer squash.

Stomatal control is the first and most important step in response to drought, as stomatal conductance reduces the rate of water loss and slows the rate of water stress development and minimizes its severity (Hanson and Hitz, 1982). Using antitranspirants will lower the surface tension of water, which increases the efficiency of water penetration and allows normal plant respiration but reduces transpiration (Lolicato, 2011).

Potassium is the main regulator of the osmotic potential in the guard cells, thereby controlling opening and closing of the stomata (Ficsher,1971) .Guard cells are relatively small cell but there is considerable variation in their size between species. The dimensions of the outer limits of the walls may vary from 10 to almost 80 micrometer in length and from a few micrometers to about 50 micrometer in width though that dimensions of width may vary according to the stomata aperture (Wilmer and Pricker 1996 ). Segura et. al.,(2015) reported that foliar application of kaolin increased stomatal density in water -stressed plants.

Water deficit has many effects on strawberry plant physiology and productivity involving reactions ranging from cellular levels to entire plant. Reducing quantities of transpiration by application of antitranspirants is a very attractive subject in agriculture as it could save considerable quantities of water and also reduce plant stress caused by water deficits. Therefore, the aim of this study was to determine irrigation intervals and antitranspirants application effect on the strawberry plant minerals content, water use efficiency and leaf stomata behavior .

\section{MATERIALS AND METHODS}

Two experiments were conducted at Elkanter Research Station, Qaluobia
Governorate during the two growing seasons of 2013 / 2014 and 2014 /2015 The soil was clammy in texture . "Festival" strawberry cultivar was used in this study. Dates of planting were September $25^{\text {th }}$ and October $2^{\text {nd }}$ in 2013 and 2014 for the first and second seasons, respectively. All agricultural practices for cultivation were performed as recommended by Ministry of Agriculture and Land Reclamation. The treatments comprised three irrigation intervals (two days common used at the farm ,three days and four days intervals) and six treatments of: tap water as control, potassium silicate $\left(\mathrm{k}_{2} \mathrm{O}_{3} \mathrm{Si}\right)$, sodium silicate $\left(\begin{array}{lll}\mathrm{Na}_{2} & \mathrm{O}_{3} \mathrm{Si}\end{array}\right)$ calcium carbonate $\left(\mathrm{CaCO}_{3}\right)$ magnesium carbonate $\left(\mathrm{MgCO}_{3}\right)$ and aluminum silicate $\left(\mathrm{Al}_{2} \mathrm{Si}_{2} \mathrm{O}_{7}\right)$ or (kaolin), the concentration was $2 \%$ used for all the treatments to improve water efficiency and reduce water requirements under drip irrigation system. The foliar spray treatments were started after 45 day from transplanting and every 15 days until the end of May. The experiment was designed in a split plot arrangement with three replications. Irrigation intervals were in the main plots and antitranspirants used to minimize water requirements were allocated in the sub plots. At planting dates the fresh transplants were dipped in Rhizolex solution at rate of $2.0 \mathrm{~g} / \mathrm{l}$ for 20 minutes as recommended before transplanting. Plants were arranged in four rows-bed system with $120 \mathrm{~cm}$ width and $30 \mathrm{~cm}$ height .Plant distances were $25 \mathrm{~cm}$ apart (16 plants $/ \mathrm{m}^{2}$ ) Plot area was $34 \mathrm{~m}^{2}$.Three beds each with $20 \mathrm{~m}$ length and $1.7 \mathrm{~m}$ width .

\section{Data recorded: 1- leaf mineral content:}

Five plants were taken from each experimental plot on March 15 to determine leaf mineral content . leaves were washed with tap water, rinsed with distilled water then weighted after air dried. Then leaves were oven dried 
at 60-70 C. Dry leaves were grounded and digested using sulphoric acid and oxygen peroxide according to leaf mineral content of $\mathrm{N}$ and $\mathrm{P}$ were determined on dry weight basis according to Jackson, (1973). The Ca, $\mathrm{K}, \quad \mathrm{Mg}, \mathrm{Na}, \mathrm{Si}, \mathrm{Fe}, \mathrm{Zn}$, and $\mathrm{Mn}$ concentrations in dry matter of leaves was determined with an inductivelycoupled plasma (ICP) spectrometer according to Stefansson (2007) .

\section{2-Water utilization efficiency (W Ut \\ E) :}

Applied irrigation water is used to describe the relationship between production and the amount of water applied . It was determined according to the following equation (Jensen 1983 ):

Water utilization efficiency $=$

Fruit yield $(\mathrm{kg})$ /feddan

Seasonal AIW ( $\mathrm{m}^{3}$ water applied /feddan )

\section{3-Water use efficiency (W.U.E.):}

The production of strawberry fruits by one cubic meter of irrigation water (fruit yield in $\mathrm{kg} / \mathrm{feddan} / \mathrm{m}^{3}$ water consumed /feddan ), as affected by different treatments was calculated by the following equation (Begg and Turner 1976) .

$$
\text { Water use efficiency }=\frac{\text { yield }(\mathrm{Kg} / \mathrm{fed})}{\text { Water quantity }\left(\mathrm{m}^{3} / \mathrm{fed}\right)}
$$

\section{4-Sccaning electron microscopy :-}

The morphological changes of stomata for leaf No.3 from different treatments were examined and calculated through a Joel Scanning Electron Microscope (T.33A) linked with the semafour software program in the Central Laboratory of the Faculty of Agriculture, Ain Shams University.

\section{Soil sample :}

Soil sample $(0-30 \mathrm{~cm})$ was collected for this study. The collected soils were air dried, crushed and sieved in $2 \mathrm{~mm}$ sieve. Some physical and chemical characteristics of the investigated soils are presented in Table (2). Soil sample from the experimental site was taken to determine the properties as: Particle size distribution was carried out using the international pipette method as described by Baruah and Barthakur (1997). Electrical conductivity was determined in the extract of saturated soil paste according to the method mentioned by Jackson (1973). pH values were measured in (1:2.5) soil suspension using $\mathrm{pH}$ meter according to the method mentioned by Black et al. (1965). Soluble cations $\left(\mathrm{Ca}^{+}, \mathrm{Mg}^{2+}, \mathrm{Na}^{+}\right.$and $\left.\mathrm{K}^{+}\right)$and anions $\left(\mathrm{Cl}, \mathrm{CO}_{3}^{-2}, \mathrm{HCO}_{3}^{-}\right.$and $\left.\mathrm{SO}_{4}^{-2}\right)$ were determined in the soil paste extract according to Jackson (1973). Available potassium was measured using Flame photometer after extracting by ammonium acetate as described by Miller and Keeney (1982).

\section{Statistical analysis:-}

Data were subjected to statistical analyzed as split plot design according to the procedure described by snedecor and Cochran (1982) . Comparison among means of treatments were tested using Duncan multiple range test .

\section{RESULTS AND DISCUSSION Mineral contents in plant dry weight :- 1- Nitrogen content :- \\ Data in Table (4) showed that, the} highest concentration of $\mathrm{N}$ was obtained with irrigation every two days intervals in the first season while in the second season there was no significant difference between irrigation each two and three days. These results were in harmony with those obtained by El-Sayed et. al., (2015)

Concerning the effect of antitranspirants as foliar application on nitrogen concentration, obtained results showed that the highest $\mathrm{N}$ concentration was resulted 
from using kaolin as antitranspirants in the first season Moreover ,there were no significant differences with application of potassium silicate in the second season. Obtained results are in agreement with Ezzat et. al.,(2009) on potato plants.As respect to the effect of interaction, results clearly indicate that foliar application of both kaolin and potassium silicate under two and three days irrigation intervals gave the highest value of $\mathrm{N}$ concentration. These results may be due to the highest leaf area of strawberry plant treated as reported in the previous paper.

Table (1): Physical and chemical properties of the experimental site:

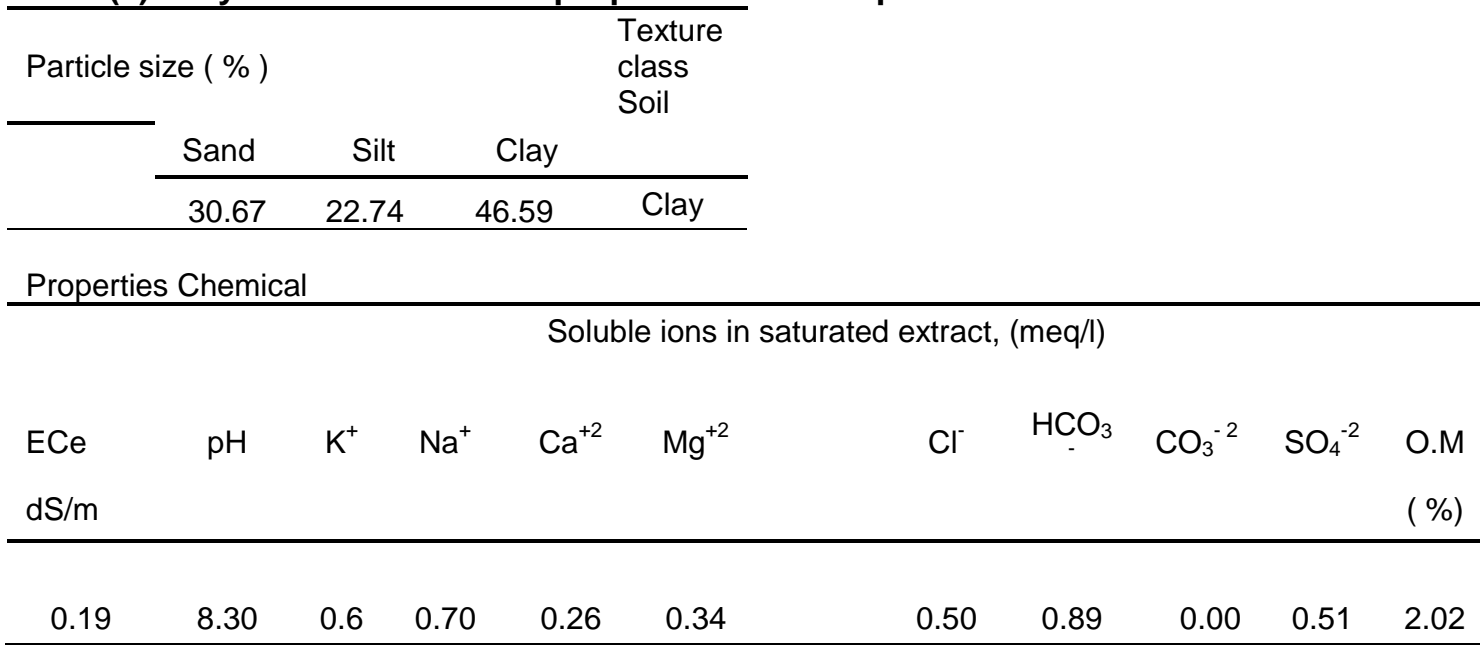

Table (2): The soil moisture constants (\% by weight) and bulk density of the experimental soil

\begin{tabular}{lllll}
$\begin{array}{l}\text { Mean soil } \\
\text { depth }(\mathrm{cm})\end{array}$ & $\begin{array}{l}\text { Bulk density } \\
\mathrm{gm} / \mathrm{cm}^{3}\end{array}$ & $\begin{array}{l}\text { Field capacity } \\
(\%)\end{array}$ & $\begin{array}{l}\text { Wilting point } \\
(\%)\end{array}$ & $\begin{array}{l}\text { Available water } \\
(\%)\end{array}$ \\
\cline { 2 - 5 } $0-45$ & 1.21 & 40.01 & 24.19 & 15.82
\end{tabular}

Table (3): Amounts of applied irrigation water quantity $\left(\mathrm{m}^{3} / \mathrm{fed}\right)$ in each irrigation intervals during the two growing seasons of $2013 / 2014$ and 2014/2015.

\begin{tabular}{lccc}
\multicolumn{3}{c}{ during the two growing seasons of $2013 / 2014$ and $2014 / 2015}$. \\
\hline $\begin{array}{c}\text { Treatments } \\
\text { Seasons }\end{array}$ & $\mathrm{I}_{1}$ & Water quantity $\left(\mathbf{m}^{3} / \mathbf{f e d}\right)$ \\
\hline $2013 / 2014$ & 3413 & $\mathrm{I}_{2}$ & $\mathrm{I}_{3}$ \\
\hline $2014 / 2015$ & 3200 & 2731 & 1920 \\
\hline Average & 3307 & 2560 & 1984 \\
\hline
\end{tabular}

$I_{1}$-Two days interval $I_{2}$ - three days interval $I_{3}$ - four days interval 
Table (4): Effect of Irrigation intervals, some antitranspirants and their interactions on $\mathrm{N}$ and $\mathbf{P}$ content \% in strawberry leaves during the two growing seasons of 2013/2014 and 2014/2015

\begin{tabular}{|c|c|c|c|c|c|c|c|c|}
\hline \multirow{3}{*}{ Characte } & \multicolumn{5}{|c|}{$\mathrm{N}$ conten } & \multicolumn{2}{|c|}{$\mathrm{P}$ content $(\%)$} & \multirow[b]{3}{*}{ Mean } \\
\hline & \multicolumn{7}{|c|}{ Irrigation intervals } & \\
\hline & $\mathrm{I}_{1}$ & $\mathrm{I}_{2}$ & $\mathrm{I}_{3}$ & Mean & $I_{1}$ & $\mathrm{I}_{2}$ & $I_{3}$ & \\
\hline \multicolumn{9}{|l|}{ Treatments } \\
\hline \multicolumn{9}{|c|}{$2013-2014$} \\
\hline Control & $1.750 \mathrm{gh}$ & $1.563 \mathrm{~h}$ & $1.506 \mathrm{~h}$ & $1.606 \mathrm{C}$ & $0.2640 \mathrm{~b}$ & $0.2627 \mathrm{~b}$ & $0.2690 \mathrm{~b}$ & 0.2652 B \\
\hline P.S. & $2.905 b c$ & $2.452 \mathrm{~cd}$ & $1.629 \mathrm{~h}$ & $2.329 \mathrm{~B}$ & $0.2680 \mathrm{~b}$ & $0.2713 b$ & $0.2730 \mathrm{~b}$ & $0.2708 \mathrm{AB}$ \\
\hline S.S. & 2.205 defg & 2.316 def & $1.846 f g h$ & $2.122 \mathrm{~B}$ & $0.2673 \mathrm{~b}$ & $0.2767 \mathrm{~b}$ & $0.2720 \mathrm{~b}$ & $0.2720 \mathrm{AB}$ \\
\hline C.C. & $2.862 b c$ & $1.840 \mathrm{gh}$ & 1.886efgh & $2.196 \mathrm{~B}$ & $0.2683 \mathrm{~b}$ & $0.2650 \mathrm{~b}$ & $0.3150 \mathrm{a}$ & $0.2828 \mathrm{~A}$ \\
\hline M.C. & $2.972 \mathrm{~b}$ & $1.778 \mathrm{gh}$ & $1.677 \mathrm{~h}$ & $2.142 \mathrm{~B}$ & $0.2750 \mathrm{~b}$ & $0.2633 \mathrm{~b}$ & $0.2737 \mathrm{~b}$ & $0.2707 \mathrm{AB}$ \\
\hline A.S. & $3.578 \mathrm{a}$ & 1.868 efgh & $2.329 \mathrm{de}$ & $2.592 \mathrm{~A}$ & $0.2753 \mathrm{~b}$ & $0.2753 \mathrm{~b}$ & $0.2717 \mathrm{~b}$ & $0.2741 \mathrm{AB}$ \\
\hline Mean & $2.712 \mathrm{~A}$ & $1.969 \mathrm{~B}$ & $1.969 \mathrm{~B}$ & & $0.2697 \mathrm{~A}$ & $0.2691 \mathrm{~A}$ & $0.2791 \mathrm{~A}$ & \\
\hline \multicolumn{9}{|c|}{ 2014-2015 } \\
\hline Control & 1.628 ef & 1.663 ef & $1.396 \mathrm{f}$ & $1.562 \mathrm{E}$ & 0.2550 cde & 0.2470 efg & $0.2400 \mathrm{~g}$ & $0.2473 \mathrm{D}$ \\
\hline P.S. & $2.548 \mathrm{bc}$ & $2.755 b$ & 1.519 ef & $2.274 \mathrm{AB}$ & $0.2603 \mathrm{~cd}$ & $0.2837 \mathrm{a}$ & $0.2833 \mathrm{a}$ & $0.2758 A$ \\
\hline S.S. & 1.791 ef & $1.972 \mathrm{de}$ & 1.722 ef & $1.828 \mathrm{D}$ & $0.2437 \mathrm{fg}$ & $0.2627 \mathrm{c}$ & $0.2633 \mathrm{c}$ & $0.2566 \mathrm{CD}$ \\
\hline C.C. & $2.463 \mathrm{bcd}$ & 1.978 cde & 1.848 ef & $2.096 \mathrm{BC}$ & 0.2517 def & $0.2573 \mathrm{~cd}$ & $0.2613 \mathrm{~cd}$ & $0.2568 \mathrm{CD}$ \\
\hline M.C. & $2.926 \mathrm{~b}$ & 1.631 ef & 1.604 ef & $2.054 \mathrm{C}$ & 2643 bc & $0.2607 \mathrm{~cd}$ & $0.2630 \mathrm{c}$ & $0.2627 \mathrm{BC}$ \\
\hline A.S. & $3.578 \mathrm{a}$ & 1.790 ef & 2.012 cde & $2.460 \mathrm{~A}$ & $0.2570 \mathrm{cde}$ & $0.2777 \mathrm{a}$ & $0.2737 \mathrm{ab}$ & $0.2694 \mathrm{AB}$ \\
\hline Mean & $2.489 \mathrm{~A}$ & $1.965 \mathrm{AB}$ & $1.683 \mathrm{~B}$ & & $2553 \mathrm{~A}$ & $48 \mathrm{~A}$ & $0.2641 \mathrm{~A}$ & \\
\hline
\end{tabular}

$\mathrm{I}_{1}$-Two days interval $\mathrm{I}_{2}$ - three days interval $\mathrm{I}_{3}$ - four days interval

P.S.- Potassium silicate S.S.- Sodium silicate C.C.- Calcium carbonate M.C.--Magnesium carbonate A.S aluminum silicate (Kaolin)Values within the column or rows followed by the same capital or small letter/s do not significantly differ from each other according to Duncan 's multiple range test at $5 \%$ level

\section{2-Phosphorus content:}

In Table (4) there were no significant influence of irrigation intervals on phosphorus concentration in the two seasons. These findings are in agreement with El-Sayed et. al., (2015) on strawberry .Application of calcium carbonate has a significant effect on $p$ concentration in the first season while in the second season the application of potassium silicate resulted in the highest $p$ concentration.
Results from interaction between irrigation every 4 days with spraying calcium carbonate, was significantly superior over many other interaction treatments in the first season. Similar results were obtained with Ahmed (2014) on banana.Spraying of kaolin had the highest Phosphorus concentration under the water stress conditions could be due to an increasing in total soluble solid in strawberry fruits in our results. 


\section{3-Potassium content :}

Table (5) showed that our results concerning potassium content did not influence by the three irrigation intervals in the two tested seasons. These result are in harmony with Jensen (2011)and disagreement with those obtained by $\mathrm{El}$ Sayed et. al.,. (2015) on strawberry. As respect to the effect of spraying antitranspirants ,the highest concentration of $\mathrm{K}$ resulted from both of potassium silicate and kaolin application in the two seasons. The highest values of $K$ content were obtained from the interaction between plants irrigated each two and four days and foliar application of potassium silicate. The highest $\mathrm{K}$ concentration might be the reasons of the highest early and total yield from this treatments( Wang and Galletta 1996 ) on strawberry.

Table (5): Effect of Irrigation intervals, some antitranspirants and their interactions on $\mathrm{K}$ and $\mathrm{Ca} \%$ in strawberry leaves during the two growing seasons of 2013/2014 and 2014/2015

\begin{tabular}{|c|c|c|c|c|c|c|c|c|}
\hline \multirow[t]{3}{*}{ Character } & \multicolumn{3}{|c|}{ K content $(\%)$} & \multicolumn{5}{|c|}{ Ca content( \%) } \\
\hline & \multicolumn{8}{|c|}{ Irrigation intervals } \\
\hline & Treatments & $\mathrm{I}_{2}$ & $I_{3}$ & Mean & $\mathrm{I}_{1}$ & $\mathrm{I}_{2}$ & $I_{3}$ & Mean \\
\hline \multicolumn{9}{|c|}{ 2013-2014 } \\
\hline Control & $1.127 \mathrm{f}$ & $0.847 \mathrm{i}$ & $0.5817 \mathrm{j}$ & $0.8518 \mathrm{~B}$ & $1.055 \mathrm{abcd}$ & $0.8270 \mathrm{ghi}$ & $0.7437 \mathrm{i}$ & $0.8752 \mathrm{C}$ \\
\hline P.S. & $1.509 a b$ & $1.089 \mathrm{fgh}$ & $1.479 \mathrm{~b}$ & $1.359 \mathrm{~A}$ & 0.8507 fghi & 0.9687 cdef & 0.8133 ghi & $0.8776 \mathrm{C}$ \\
\hline S.S. & $1.548 \mathrm{a}$ & $1.065 \mathrm{gh}$ & $1.048 \mathrm{~h}$ & $1.221 \mathrm{AB}$ & 0.8203 ghiu & $1.053 \mathrm{abcd}$ & 0.7650 hi & $0.8796 \mathrm{C}$ \\
\hline C.C. & $1.376 \mathrm{c}$ & $1.058 \mathrm{gh}$ & $1.098 \mathrm{fg}$ & $1.177 \mathrm{AB}$ & $1.133 \mathrm{ab}$ & $1.031 \mathrm{abcd}$ & $1.155 \mathrm{a}$ & $1.106 \mathrm{~A}$ \\
\hline M.C. & $1.131 \mathrm{f}$ & $1.208 \mathrm{e}$ & $0.8033 \mathrm{i}$ & $1.048 \mathrm{AB}$ & $1.061 \mathrm{abc}$ & 0.8947 efgh & 0.8417 fghi & $0.9326 \mathrm{C}$ \\
\hline A.S. & $1.392 \mathrm{c}$ & $1.282 \mathrm{~d}$ & $1.292 \mathrm{~d}$ & $1.322 \mathrm{~A}$ & 1.019 bcde & $1.113 a b$ & 0.9293 defg & $1.021 \mathrm{~B}$ \\
\hline Mean & $1.347 \mathrm{~A}$ & $1.092 \mathrm{~A}$ & $1.050 \mathrm{~A}$ & & $0.9899 \mathrm{~A}$ & $0.9813 \mathrm{~A}$ & $0.8747 \mathrm{~A}$ & \\
\hline \multicolumn{9}{|c|}{ 2014-2015 } \\
\hline Control & 0.8300 hij & 0.8400 hij & $0.6207 \mathrm{j}$ & $0.7636 \mathrm{D}$ & $1.011 \mathrm{bc}$ & 0.8193 efg & $0.7627 \mathrm{~g}$ & $0.8644 \mathrm{C}$ \\
\hline P.S. & $1.482 a b$ & 0.9980 efgh & $1.553 \mathrm{a}$ & $1.344 \mathrm{~A}$ & $0.7940 \mathrm{fg}$ & 0.9217 cdef & $0.7817 \mathrm{~g}$ & $0.8643 \mathrm{C}$ \\
\hline S.S. & $1.377 \mathrm{abc}$ & $0.7240 \mathrm{ij}$ & $0.9693 \mathrm{FGH}$ & $1.023 \mathrm{BC}$ & $0.8023 \mathrm{fg}$ & $1.029 a b c$ & $0.7620 \mathrm{~g}$ & $0.8324 \mathrm{C}$ \\
\hline C.C. & $1.337 \mathrm{abc}$ & $0.9057 \mathrm{ghi}$ & $1.131 \mathrm{cdefg}$ & $1.125 \mathrm{ABC}$ & $1.021 \mathrm{abc}$ & $0.9663 \mathrm{bcd}$ & $1.149 \mathrm{a}$ & $1.046 \mathrm{~A}$ \\
\hline M.C. & 1.008 defgh & $1.191 \mathrm{cdef}$ & 0.8130 hij & $1.004 \mathrm{C}$ & $1.044 \mathrm{abc}$ & 0.8797 defg & 0.8153 efg & $0.9130 \mathrm{~B}$ \\
\hline A.S. & 1.244 bcde & $1.261 \mathrm{bcd}$ & 1.249 bcde & $1.251 \mathrm{AB}$ & $1.036 \mathrm{abc}$ & $1.064 a b$ & 0.9380 bcde & $1.013 \mathrm{~A}$ \\
\hline Mean & $1.213 \mathrm{~A}$ & $0.9867 \mathrm{~A}$ & $1.056 \mathrm{~A}$ & & $0.9514 \mathrm{~A}$ & $0.9466 \mathrm{~A}$ & $0.8681 \mathrm{~A}$ & \\
\hline
\end{tabular}

$I_{1}$-Two days interval $I_{2}$ - three days interval $I_{3}$ - four days interval

P.S.- Potassium silicate S.S.- Sodium silicate C.C.- Calcium carbonate M.C.--Magnesium carbonate A.S aluminum silicate

(Kaolin)Values within the column or rows followed by the same capital or small letter /s do not significantly differ from each other according to Duncan 's multiple range test at $5 \%$ level 


\section{4-Calcium content:}

Table (5) indicates that the effect of irrigation intervals on the $\mathrm{Ca}$ concentration has non significant influence in the two tested seasons Our results agree with (Jensen 2011) on strawberry. Concerning of the antitranspirants, results indicates that spraying of both calcium carbonate and kaolin resulted in a significant increase in $\mathrm{Ca}$ concentration in the two tested seasons. Results are in harmony with Morley et. al., (1993) and de Kreij (1999). It was noticed from Table (5) that irrigation each two days gave the highest $\mathrm{Ca}$ concentration in the two seasons. These treatments resulted in the highest values of fruit firmness in our study.

\section{5-Silicon content :}

Table (6) shows that the increase in irrigation interval from 2 to 4 days led to a significant decrease of $\mathrm{Si}$ concentration in strawberry leaves in the first season only. On the other hand, three irrigation intervals had no significant effect on Si concentration.

Table (6): Effect of Irrigation intervals, some antitranspirants and heir interactions on $\mathrm{Mg}$ $\%$ and $\mathrm{Si}$ ppm in strawberry leaves during the two growing seasons of 2013/2014 and 2014/2015

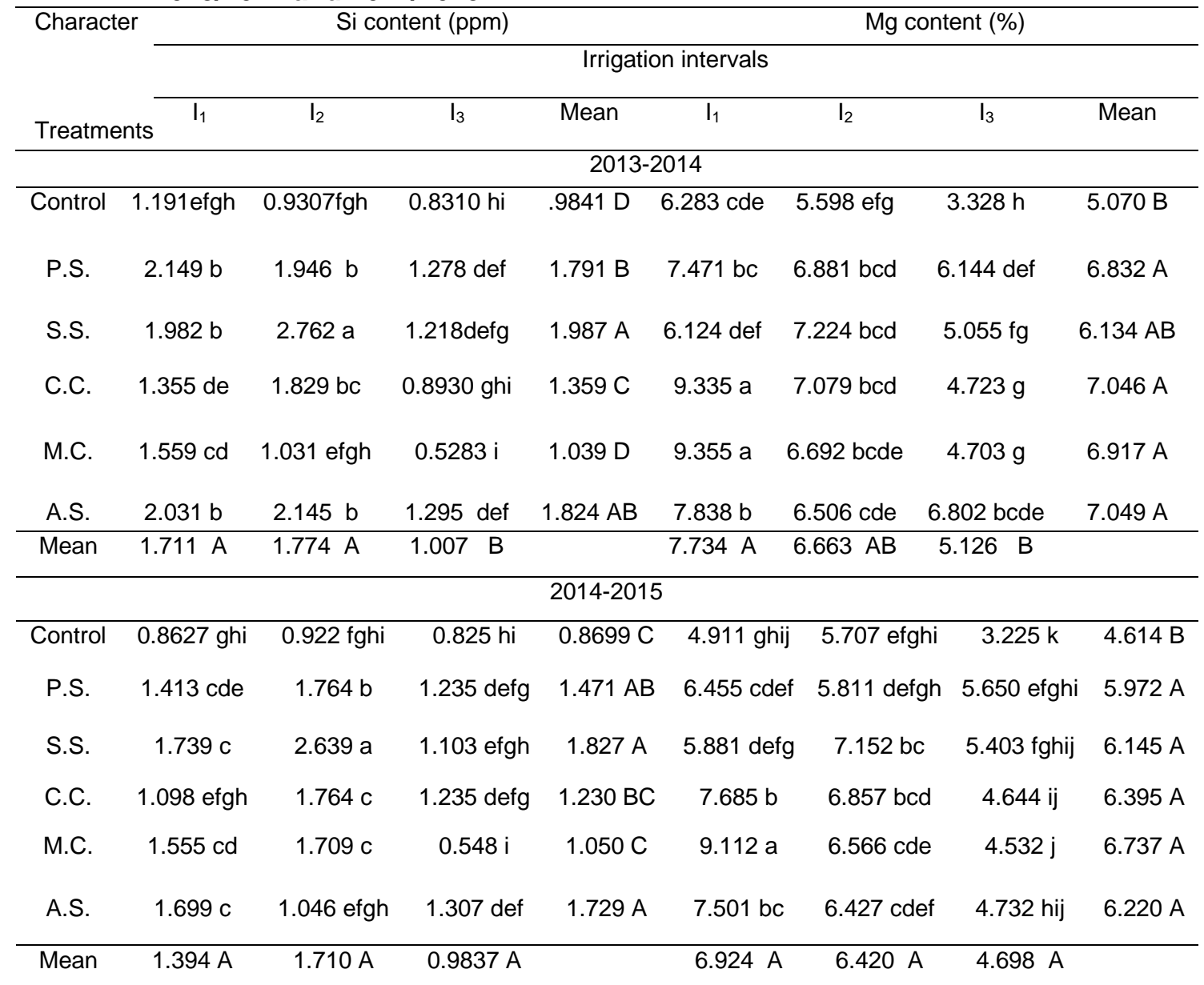

$\mathrm{I}_{1}$-Two days interval $\mathrm{I}_{2}$ - three days interval $\mathrm{I}_{3}$ - four days interval

P.S.- Potassium silicate S.S.- Sodium silicate C.C.- Calcium carbonate M.C.--Magnesium carbonate A.S aluminum silicate (Kaolin)Values within the column or rows followed by the same capital or small letter/s do not significantly differ from each other according to Duncan 's multiple range test at $5 \%$ level 
Regarding to the effect of antitranspirants obtained data in Table (6) revealed that a significant increase obviously noticed in the Si concentration with the application of each of potassium, aluminum and sodium silicate in the two tested seasons. These treatments could be caused the increase of fruit yield compared to the control. Such results were obtained by Yasuto and Takahashi (1986)

With respect to the interaction, It is evident from results in Table (6) that the highest $\mathrm{Si}$ concentration increased with irrigation every 3 days with spraying sodium silicate followed by potassium silicate .

\section{6- Magnesium content:}

Table (6) revealed the effect of irrigation intervals on $\mathrm{Mg}$ concentration it was noticed that the highest values of $\mathrm{Mg}$ concentration was recorded from irrigated plants each two days .with no significant differences with irrigation each three days plants in the first season.While in the second season there were no significant differences noticed among the three irrigation intervals on $\mathrm{Mg}$ concentration. Application of all antitranspirants has a significant effect as Table (6) illustrates compared with control. The effect of interaction between irrigation periods and antitranspirants, obviously noticed that when decreasing irrigation intervals to 2 days and spraying $\mathrm{MgCO}_{3}$ and $\mathrm{CaCO}_{3}$ this caused the highest $\mathrm{Mg}$ concentration.

\section{7-Sodium content:}

Data in Table (7) clearly indicate that increasing the irrigation interval from two days to three or four days led to a significant decrease in the $\mathrm{Na}$ concentration in the first season. However, in the second season no significant differences were noticed between 2and 3days irrigation intervals .Such results were obtained by Jensen (2011) on strawberry.
As respect of the effect of antitranspirants on $\mathrm{Na}$ concentration, results in Table (7) indicated that spraying with sodium silicate which is significantly superior over the other antitranspirants treatments in the two tested seasons.Same results were obtained by (Wang and Galletta 1996) on strawberry .Also it was noticed that from Table (7) the interaction between irrigation every 2 or 3 days with application of sodium silicate gave the highest values of $\mathrm{Na}$ concentration in two seasons of study .

\section{8-Iron content:}

Table (7) illustrates the effect of irrigation periods on $\mathrm{Fe}$ concentration. It was clear that irrigation each two or three days recorded the highest Fe concentration in the first season. In addition, there were no significant differences between irrigation each two or three days compared to the irrigation each four days in the second season. Similar findings were reported by Ezzat et al (2009) on potato. With respect to the influence of antitranspirants treatments it is clear from Table (7) that spraying of kaolin resulted in a significant increase in $\mathrm{Fe}$ concentration in both seasons.

Moreover, the irrigation each three days and spraying of kaolin is the best interaction treatment which led to a significant increase in the Fe concentration in strawberry foliage dry weight.

\section{9 -Manganese content :}

Results presented in Table (8) show that the highest $\mathrm{Mn}$ concentration was resulted from irrigation each four days and significantly decreased under two or three days without significant differences in the two tested seasons. These results are not in agreement with those of Ezzat et al. (2009)they mentioned that the uptake of microelements was decreased with the reduction of water requriments on potato tubers. Data in Table (8) reveal that foliar 
application of only potassium silicate increased the $\mathrm{Mn}$ concentration in the first season and it did not significantly differ with sodium silicate, calcium carbonate and kaolin. As for the interaction effect on $\mathrm{Mn}$ concentration treatment with potassium silicate under water stress (irrigation each four days ) recorded the highest value.

Table (7): Effect of irrigation intervals, some antitranspirants and their interactions on $\mathrm{Na}$ and $\mathrm{Fe}$ in strawberry leaves during the two growing seasons of 2013/2014 and 2014/2015

\begin{tabular}{|c|c|c|c|c|c|c|c|c|}
\hline \multirow{2}{*}{ Character } & \multicolumn{4}{|c|}{ Na content( ppm) } & \multicolumn{4}{|c|}{ Fe content( ppm) } \\
\hline & \multicolumn{8}{|c|}{ Irrigation intervals } \\
\hline & $I_{1}$ & $\mathrm{I}_{2}$ & $I_{3}$ & Mean & $I_{1}$ & $\mathrm{I}_{2}$ & $I_{3}$ & Mean \\
\hline \multicolumn{9}{|c|}{ Treatments } \\
\hline \multicolumn{9}{|c|}{ 2013-2014 } \\
\hline Control & $0.5567 \mathrm{~b}$ & $0.01133 \mathrm{c}$ & $0.07333 \mathrm{c}$ & $0.2478 \mathrm{~B}$ & $1.240 \mathrm{bcd}$ & $0.7080 \mathrm{fgh}$ & 0.8450 efgh & $0.9310 \mathrm{C}$ \\
\hline P.S. & $0.1767 \mathrm{c}$ & $0.1033 \mathrm{c}$ & $0.04000 \mathrm{c}$ & $0.1067 \mathrm{C}$ & $1.360 \mathrm{~b}$ & 0.9990 def & $0.6650 \mathrm{gh}$ & $1.008 \mathrm{BC}$ \\
\hline S.S. & 0.8367 a $c$ & $0.7500 a b$ & $0.1033 \mathrm{c}$ & $0.5633 \mathrm{~A}$ & 1.023 cdef & $1.427 b$ & 0.9307 defg & $1.127 \mathrm{~B}$ \\
\hline C.C. & $0.0600 \mathrm{c} 0$ & 0.02000 c & $0.02000 \mathrm{c}$ & $0.03333 \mathrm{D}$ & 0.8880 efg & $1.333 \mathrm{bc}$ & $0.5380 \mathrm{~h}$ & $0.9196 \mathrm{C}$ \\
\hline M.C. & $0.0433 \mathrm{c}$ & $0.1267 \mathrm{c}$ & $0.03000 \mathrm{c}$ & $0.06667 \mathrm{CD}$ & $1.384 b$ & $1.210 \mathrm{bcd}$ & $0.6143 \mathrm{gh}$ & $1.069 \mathrm{BC}$ \\
\hline A.S. & $0.0400 \mathrm{c}$ & $0.1267 \mathrm{c}$ & $0.02000 \mathrm{c}$ & $0.06222 \mathrm{D}$ & $1.209 \mathrm{bcd}$ & $1.780 \mathrm{a}$ & 1.033 cde & $1.341 \mathrm{~A}$ \\
\hline Mean & $0.2856 \mathrm{~A}$ & $0.2067 \mathrm{~B}$ & $0.04778 \mathrm{C}$ & & $1.184 \mathrm{~A}$ & $1.243 \mathrm{~A}$ & $0.7710 \mathrm{~B}$ & \\
\hline \multicolumn{9}{|c|}{ 2014-2015 } \\
\hline Control & $0.3733 a b c$ & $0.1110 \mathrm{c}$ & $0.07067 \mathrm{c}$ & $0.1850 \mathrm{~B}$ & 1.166 cde & $0.5727 \mathrm{j}$ & $0.6053 \mathrm{ij}$ & $0.7814 \mathrm{D}$ \\
\hline P.S. & $0.1767 \mathrm{bc}$ & $0.0983 \mathrm{c}$ & $0.03187 c$ & $0.1023 B C$ & 1.162 cdef & 0.8860 efghi & i 0.6940 hij & $0.9139 \mathrm{CD}$ \\
\hline S.S. & $0.7833 \mathrm{a}$ & $0.7467 a b$ & $0.1007 \mathrm{c}$ & $0.5436 \mathrm{~A}$ & 1.082 def & $1.379 \mathrm{bc}$ & 0.7870 ghij & $1.083 \mathrm{~B}$ \\
\hline C.C. & $0.06100 \mathrm{c}$ & $0.0187 \mathrm{c}$ & $0.01950 \mathrm{c}$ & $00.3306 \mathrm{C}$ & 0.8737 fghi & 0.981 defgh & 0.7613 ghij & $0.8719 \mathrm{D}$ \\
\hline M.C. & $0.05600 \mathrm{c}$ & $0.1117 \mathrm{c}$ & $0.02440 \mathrm{c}$ & $0.06402 \mathrm{C}$ & $1.475 a b$ & 1.020 defg & $0.6237 \mathrm{ij}$ & $1.040 \mathrm{BC}$ \\
\hline A.S. & $0.03467 c$ & $0.1180 \mathrm{c}$ & $0.01483 \mathrm{c}$ & $0.05583 \mathrm{C}$ & $1.262 \mathrm{bcd}$ & $1.75 \mathrm{a}$ & 0.979 defgh & $1.331 \mathrm{~A}$ \\
\hline Mean & $0.2475 \mathrm{~A}$ & $0.2007 \mathrm{~A}$ & $0.04366 \mathrm{~B}$ & & $1.170 \mathrm{~A}$ & $1.098 \mathrm{AB}$ & $0.7417 \mathrm{~B}$ & \\
\hline
\end{tabular}

$I_{1}$-Two days interval $I_{2}$ - three days interval $I_{3}$ - four days interval

P.S.- Potassium silicate S.S.- Sodium silicate C.C.- Calcium carbonate M.C.-Magnesium carbonate A.S - aluminum silicate (Kaolin)Values within the column or rows followed by the same capital or small letter is do not significantly differ from each other according to Duncan 's multiple range test at $5 \%$ level 
Table (8): Effect of Irrigation intervals, some antitranspirants and their interactions on Mn and $\mathrm{Zn}$ in strawberry leaves during the two growing seasons of 2013/2014 and 2014/2015

\begin{tabular}{|c|c|c|c|c|c|c|c|c|}
\hline \multirow{3}{*}{ Character } & \multicolumn{4}{|c|}{ Mn content (ppm) } & \multicolumn{4}{|c|}{ Zn content ( ppm) } \\
\hline & \multicolumn{8}{|c|}{ Irrigation intervals } \\
\hline & $I_{1}$ & $\mathrm{I}_{2}$ & $I_{3}$ & Mean & $I_{1}$ & $\mathrm{I}_{2}$ & $I_{3}$ & Mean \\
\hline \multicolumn{9}{|l|}{ Treatments } \\
\hline \multicolumn{9}{|c|}{$2013-2014$} \\
\hline Control & $0.123 \mathrm{fg}$ & $0.1160 \mathrm{~g}$ & $0.1140 \mathrm{~g}$ & $0.1177 \mathrm{D}$ & $0.05100 \mathrm{ab}$ & $0.03733 b$ & $0.04933 a b$ & $0.04589 \mathrm{~A}$ \\
\hline P.S. & 0.142 def & $0.1503 d$ & $0.2100 \mathrm{a}$ & $0.1673 \mathrm{~A}$ & $0.06400 \mathrm{a}$ & $0.06133 a b$ & $0.06500 a$ & $0.06344 \mathrm{~A}$ \\
\hline S.S. & 0.140 def & $0.1397 \mathrm{def}$ & $0.1777 \mathrm{~b}$ & $0.1526 \mathrm{~B}$ & $0.06100 \mathrm{ab}$ & $0.05700 \mathrm{ab}$ & $0.06300 \mathrm{a}$ & $0.060 .3 \mathrm{~A}$ \\
\hline C.C. & $0.1493 \mathrm{de}$ & $0.1283 \mathrm{fg}$ & $0.1743 \mathrm{bc}$ & $0.1507 \mathrm{~B}$ & $0.05800 \mathrm{ab}$ & $0.04700 \mathrm{ab}$ & $0.06267 \mathrm{a}$ & $0.05589 \mathrm{~A}$ \\
\hline M.C. & $0.116 \mathrm{~g}$ & 0.1293 efg & $0.1570 \mathrm{~cd}$ & $0.1342 \mathrm{C}$ & $0.04600 \mathrm{ab}$ & $0.06067 \mathrm{ab}$ & $0.06367 \mathrm{a}$ & $0.05678 \mathrm{~A}$ \\
\hline A.S. & $0.115 \mathrm{~g}$ & $0.1500 d$ & 0.1430 def & $0.1361 \mathrm{C}$ & $0.04833 a b$ & $0.05433 a b$ & $0.06900 \mathrm{a}$ & $0.05722 \mathrm{~A}$ \\
\hline Mean & $0.131 \mathrm{~B}$ & $0.1356 \mathrm{~B}$ & $0.1627 \mathrm{~A}$ & & $0.05472 \mathrm{~A}$ & $0.05294 \mathrm{~A}$ & $0.06211 \mathrm{~A}$ & \\
\hline \multicolumn{9}{|c|}{$2014-2015$} \\
\hline Control & 0.1223 defg & $0.102 \mathrm{gh}$ & 0.114 efg & $0.113 \mathrm{C}$ & 0.04900 efg & $0.03633 \mathrm{~h}$ & 0.0 5167ef & $0.04567 \mathrm{E}$ \\
\hline P.S. & 0.139 cdef & $0.072 \mathrm{~h}$ & $0.211 \mathrm{a}$ & $0.147 \mathrm{~A}$ & $0.05533 \mathrm{cde}$ & $0.06033 \mathrm{bcd}$ & $0.06300 \mathrm{ab}$ & $0.05956 \mathrm{AB}$ \\
\hline S.S. & 0.127 defg & 0.128 defg & $0.185 a b$ & $0.141 \mathrm{AB}$ & $0.06167 \mathrm{abc}$ & $0.05533 \mathrm{cde}$ & $0.06233 \mathrm{ab}$ & $0.05978 \mathrm{~A}$ \\
\hline C.C. & 0.129 defg & $0.126 \mathrm{defg}$ & 0.172 bc & $0.142 \mathrm{AB}$ & $0.05533 \mathrm{cde}$ & $0.04367 \mathrm{~g}$ & $0.06500 \mathrm{ab}$ & $0.05189 \mathrm{D}$ \\
\hline M.C. & $0.110 \mathrm{fg}$ & 0.117 efg & $0.154 \mathrm{bcd}$ & $0.127 \mathrm{BC}$ & $0.04700 \mathrm{fg}$ & 0.05000 efg & $0.06300 \mathrm{ab}$ & $0.05300 \mathrm{CD}$ \\
\hline A.S. & 0.115 efg & 0.146 cde & $0.136 \mathrm{def}$ & $0.132 \mathrm{AB}$ & $0.04667 \mathrm{fg}$ & $0.05400 \mathrm{de}$ & $0.06800 \mathrm{a}$ & $0.05622 B C$ \\
\hline Mean & $0.124 \mathrm{AB}$ & $0.115 \mathrm{~B}$ & $0.161 \mathrm{~A}$ & & $0.05094 \mathrm{AB}$ & $0.04994 \mathrm{~B}$ & $0.06217 \mathrm{~A}$ & \\
\hline
\end{tabular}

$\mathrm{I}_{1}$-Two days interval $\mathrm{I}_{2}$ - three days interval $\mathrm{I}_{3}$ - four days interval

P.S.- Potassium silicate S.S.- Sodium silicate C.C.- Calcium carbonate M.C.--Magnesium carbonate A.S aluminum silicate

(Kaolin)Values within the column or rows followed by the same capital or small Itter /s do not significantly differ from each other according to Duncan 's multiple range test at $5 \%$ level

\section{0-Zinc content:}

Data in Table (8) clearly indicate using the three irrigation intervals under study on $\mathrm{Zn}$ concentration. These results are not in agreement with those of Ezzat et. al., (2009) on potato. It is obvious from results in Table (8) that all antitranspirants as well as the untreated plants in the first season did not reflect any significant effect on $\mathrm{Zn}$ concentration. On the other hand, foliar application of antitranspirants had a significant differences on $\mathrm{Zn}$ concentration in the second season.

Interactions between all the antitranspirants and irrigate plants each four days had the highest values of $\mathrm{Zn}$ concentration in the two tested seasons. 


\section{Water use efficiency (WUE):}

Data presented in Table ( 9 ) indicate that the values of WUE increased with decreasing frequent irrigation in both seasons. The present data imply that high soil moisture increased the amount of water required to produce the unit value of yield. Treatments with higher amount of seasonal consumptive use of water had generally lower WUE values. Cabello et. al., (2009) and Zeng et. al., (2009) came to similar trends. The increased WUE by antitranspirants has been also reported by Bafeel and Moftah (2008) on eggplant. The relative increases in total yield were about 2731 and $2560 \mathrm{~m} 3$ water/fad., as compared to treatment in the 1st and 2nd seasons, respectively. These result were found to agree with those reported by Kirnak et.al., (2003) and Linnemannstons et. al., (2013) on strawberry.
Respecting WUE, the highest was recorded ( 6.34 and $6.27 \mathrm{Kg} / \mathrm{m} 3$ water in the first and second seasons, respectively) were obtained when strawberry plants were irrigated with the lowest rate of water. The increase in total yield might be due to the increase in average fruit weight. Also, this might be due to the favorable effect of higher amounts of irrigation water on vegetative growth photosynthetic pigments and nutrient uptake.

Saving amount of water were $40 \%$ from four days : two days, $25 \%$ from four days :three days and $20 \%$ from three days : two days which increased productivity per unit of water $17.87 \%, 6.29 \%$ and $10.9 \%$ in the first season and $17.13,8.29$ and 8.17 $\%$ in the second season, respectively.

Table (9): Effect of Irrigation intervals and some antitranspirants on water utilization efficiency $\left(\mathrm{kg} / \mathrm{m}^{3}\right)$ during the two growing seasons of 2013/2014 and 2014/2015

\begin{tabular}{ccccc}
\hline Character & \multicolumn{5}{c}{ water use efficiency $\left(\mathrm{kg} / \mathrm{m}^{3}\right)$} \\
\cline { 2 - 5 } Treatments & \multicolumn{5}{c}{ Irrigation intervals } \\
\cline { 2 - 5 } Control & $\mathrm{I}_{1}$ & $\mathrm{I}_{2}$ & $\mathrm{I}_{3}$ & Mean \\
P.S. & 5.08 & 3.52 & 3.29 & 3.96 \\
S.S. & 5.46 & 6.37 & 6.74 & 6.19 \\
C.C. & 5.05 & 6.17 & 6.56 & 5.92 \\
M.C. & 5.55 & 6.68 & 7.03 & 6.42 \\
A.S. & 5.59 & 6.56 & 7.14 & 6.43 \\
Mean & 5.54 & 6.48 & 7.26 & 6.43 \\
\hline & 5.38 & 5.96 & 6.34 & 5.89 \\
\hline Control & 5.14 & 2.66 & 2.99 & 3.60 \\
P.S. & 5.13 & 6.45 & 6.72 & 6.10 \\
S.S. & 5.15 & 6.34 & 6.51 & 6.00 \\
C.C. & 5.32 & 6.79 & 6.67 & 6.26 \\
M.C. & 5.68 & 6.35 & 7.22 & 6.42 \\
A.S. & 5.70 & 6.15 & 7.51 & 6.45 \\
\hline Mean & 5.35 & 5.79 & 6.27 & 5.81 \\
\hline
\end{tabular}

$\mathrm{I}_{1}$-Two days interval $\mathrm{I}_{2}$ - three days interval $\mathrm{I}_{3}$ - four days interval Control P.S.- Potassium silicate S.S.Sodium silicate C.C.- Calcium carbonate M.C.--Magnesium carbonate A.S - aluminum silicate (Kaolin) 


\section{Sccaning electron microscopy (SEM) of stomata}

Stomatal control is the first and most important step in response to drought Hanson and Hitz, (1982). Sccaning electron microscopy (SEM) stomatal analysis behavior and morphology confirmed that the control leaves had mostly open stomata Fig (1) therefore , an increasing in respiration and water loss resulted in significantly decreases in yield, this results are in harmony with Farooq et. al., (2009) ,Cornic, (2000) and Abdel-Monnem, (2015) .

On the other hand ,foliar spraying of any of the antitranspirants under study had mostly closed or partially -closed stomata therefore, all of antitranspirants induced closure of plant's stomata resulting in allows plant respiration but reduces transpiration that may be reduced by the application of chemical compounds that increase leaf resistance to diffusion of water (Anderson and Kreith1978 and Lipe and Wendt, 2008). Our results are Similar to Lolicato,( 2011). However, antitranspirants differed among themselves in their influencing on the stomatal aperture .Also, figs (2 to 6) showed the gradually response to opening or closing the guard cells depending on the antitranspirants material used whereas, sodium silicate ,kaolin , potassium silicate, ranked the first treatments followed by magnesium carbonate and calcium carbonate, respectively. With respect to potassium silicate, leaves treated had mostly partially closed stomata that may be due to the potassium which play an important role in regulative the osmotic potential in the guard cells Fisher,(1971). In addition ,kaolin treated leaves showed the highest stomata density, swollen cells and partially closed stomata .kaolin could enhance cuticle transpiration not from via stomata as found by Nakano (1996) on tomato and Lipe and Wendt (2008).

It could be concluded that antitranspirants conserve the water of plant from lost to the atmosphere through transpiration and they had a potential for reducing transpiration water loss without significantly reducing photosynthetic rate of carbon dioxide in the mesophyll, as reported to (Brown and Rosenberg, 1973 and Lolicato, 2011).

The Size of stomata and guard cell varied from the antitranspirants treatments so dimensions of width may vary according to the stomata aperture (Wilmer and Pricker, 1996). Table (10) and figs (3) and (4) indicate that the lowest stomata width $(\mu \mathrm{m})$ were obtained from the Potassium silicate, Kaolin and Sodium silicate respectively. In addition kaolin treatment resulted in the lowest Stomata length $(\mu \mathrm{m})$ and increased in stomata number. In regard to kaolin, our results are in harmony with (Segura et. al., (2015). Also, such results are similar to with (Srinivasa, 1986)who found that Kaolin caused in $20-33 \%$ of stomata closed in different tomato cultivars.

Table (10) :Effect of the antitranspirants on the stomata size ( $\mu \mathrm{m})$.

\begin{tabular}{lcc}
\hline Treatments & $\begin{array}{c}\text { Stomata width } \\
(\mu \mathrm{m})\end{array}$ & $\begin{array}{c}\text { Stomata length } \\
(\mu \mathrm{m})\end{array}$ \\
\hline Control & 5.10 & 10.7 \\
Sodium silicate & 4.09 & 12.2 \\
Aluminum silicate & 3.60 & 8.69 \\
Potassium silicate & 3.44 & 12.1 \\
Magnesium carbonate & 5.35 & 10.5 \\
Calcium carbonate & 5.17 & 10.1 \\
\hline
\end{tabular}




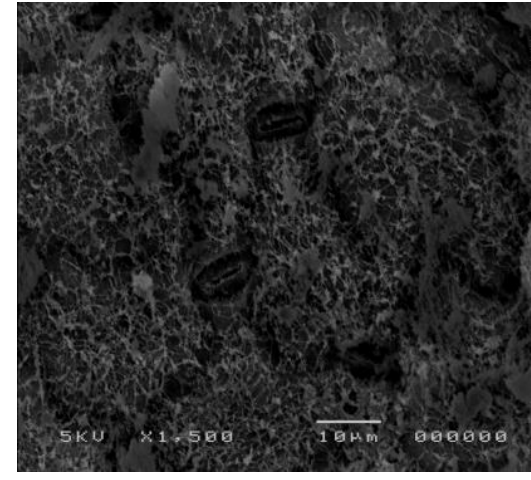

Fig ( 1$)$ Control

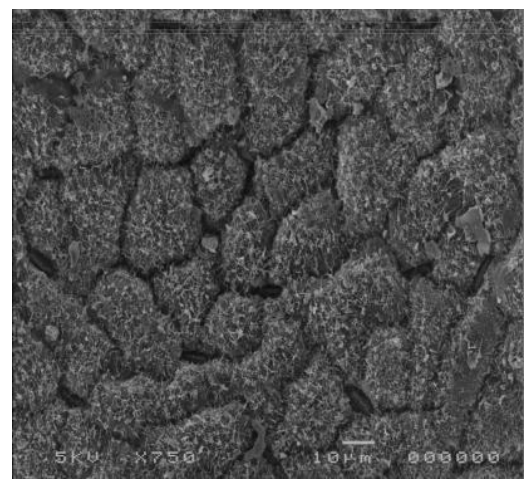

Fig $_{(3)}$ Kaolin

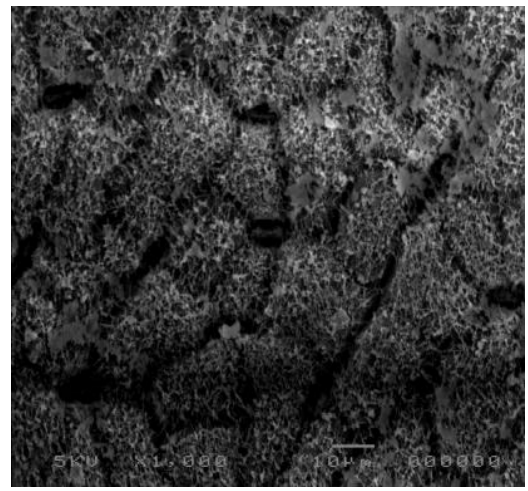

Fig (5 )Magnesium carbonate

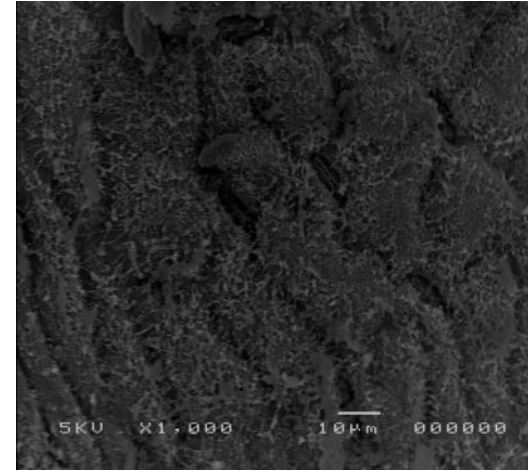

Fig (2 )Sodium silicate

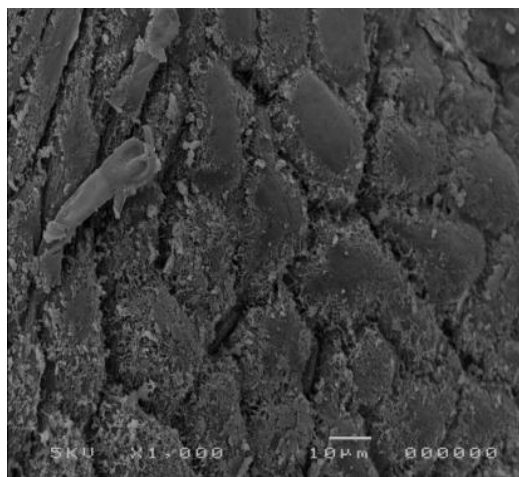

Fig $_{(4)}$ Potassium silicate

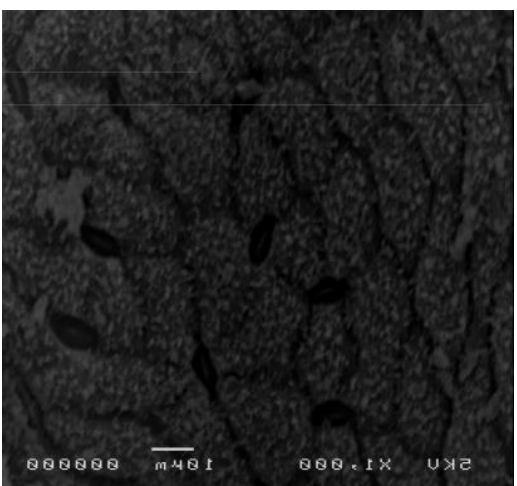

Fig (6) Calcium carbonate

Figures (1 to 6) of Scanning Electron Microscope images of strawberry leaves shown each representative of five specimens of $2 \mathrm{~cm}$ from different parts of strawberry leaf for each specimen, 20 fields of view were examined Bar is $10(\mu \mathrm{m})$. 


\section{REFERENCES}

Abdel-Monnem, S. K. (2015). Effect of Drip Irrigation Intervals and Some Antitranspirants on the Water Status, Growth and Yield of Potato (Solanum tuberosum L.), Journal of Agricultural Science and Technology 5: 15-23 .

Abdel- Rheem, H. A. (2003). Effect of water stress and potassium fertilization on yield quantity and quality of potato $\mathrm{Ph}$. D . Thesis, Fac . Agric ., Minia Univ., Egypt.

Ahmed, Y.M.A. (2014). Impact of Spraying some antitranspirants on fruiting of Williams Bananas grown under Aswan region conditions .Stem Cell 5 (4): 34-39.

Ahmet, E., S. Suat, K. Cenk and G. Ibrahim (2004). Irrigation frequency and amount affect yield components of summer squash (Cucurbita pepo L.). Agric. Water Manage., 67 (1): 63-76.

Anderson, C.J. and F. Kreith (1987). Effects of film forming and silicone antitranspirants on four herbaceous plant species Plant and Soil,49 (1):161-173.

Bafeel, S. O. and A. E. Moftah (2008). Physiological response of eggplants grown under different irrigation regimes to antitransplant treatments. Saudi J. of Biolo. Sciences, 15 (2): 259-267.

Baruah, T.C. and H.P. Barthakur (1997). A Textbook of Soil Analysis. pp. 35-67. Vikas Publishing Housing, PVTLTD, New Delhi

Begg, J.E. and N. C. Turner (1976) . Crop water deficits Advances in Agron., 28, pp. 189.

Black, C. A., D. D. Evans, L. E. Ensminger, J.L. White, F. E. Clark and R. C. Dinauer (1965). Method of soil analysis .II :chemical and microbiological properties .Amer. Soc. Agron. Inc.

Bull., Madison, Wisconsin, USA.

Brown, K. W. and N. J. Rosenberg (1973). A resistance model to predict evapotranspiration and its application to a sugar beet field. Agronomy Journal 65: 341-347.

Cabello, M.J., M.T. Castellanos, F. Romojaro, C. Martı'nez-Madrid and F. Ribas (2009). Yield and quality of melon grown under different irrigation and nitrogen rates. Agric. Water Manage., 96:866 - 874 .

Cornic, G. (2000). Drought stress inhibits photosynthesis by decreasing stomatal aperture by affecting ATP. Synthesis Trend in Plant Sci.5:187- 188 .

de Kreij, C. (1999). Production, blossom-end wet, and cation uptake of sweet pepper as affected by sodium, cation ratio, and EC of the nutrient solution. Gartenbauwissenschaft 64: 158-164.

El- Khawaga, A.S. and A.E.M. Mansour (2014). Enhancing the efficiency of irrigation water use by using some antitranspirants in Wonderful pomegranate orchards. Middle East Journal of Agric. Res. 3(3): 694-700.

El-Sayed, E., G.S.A. Eisa and I.Z.A. El Shimi (2015). Effect of irrigation water quality and treating with diatomite on productivity, water use efficiency and anatomical characters strawberry plants grown in sandy soil . Zagazig J. Agric . Res., Vol . 42 N O. (3) 457-473 .

Ezzat, A. S., U.M. Saif Eldeen and A.M. Abd El-Hameed (2009). Effect of irrigation water quantity antitranspirants and humic acid on growth, yield nutrients content and water use efficiency of potato (Solanum tuberosum J. Agric.Sci. Mansoura Univ., (12) : 11585-11603.

Fischer R. A. (1971). Role of potassium in stomatal opening in the leaf of Vicia faba Plant Physiol. 47, 555-558 .

Francisco, M. and S. R. Jose (2009). Effects of Antitranspirants Spray and Potassium: Calcium: Magnesium Ratio on Photosynthesis, Nutrient and Water Uptake, Growth, and Yield of Sweet Pepper Journal of Plant Nutrition, 32: 97111.

Farooq, M., A. Wahid, N. Kobayashi, D. Fujita and SMA. Barsa (2009). Plant drought stress effects, mechanisms and management Agronomy for Sustainable Development 29: 185-212 .

Hanson, A.D. and D. Hitz w (1982). Metabolic responses of mesophytes to plant and water deficits. Ann. Rev. of Plant Physiol., 33: 163-203.

Jackson, M. L. (1973). Soil chemical analysis .Prentice-Hall of India Private Limited, New Delhi. pp. 521. 
Jensen , M.E. (1983). Design and operation of farm irrigation systems .Amer. Soc. Agric. Eng. Michigan, USA, p. 827.

Jensen N. L.(2011) . Physiological adaptation and fruit quality of Fragaria xananassa under different deficit irrigation strategies and salt treatments .Ph.D. Thesis: Department of Agriculture and Ecology, University of Copenhagen \& Department of Horticulture, Aarhus University

Kirnak, H., C. Kaya, D. Higgs, I. Bolat, M. Simsek and A. Ikinci (2003). Effects of preharvest drip-irrigation scheduling on strawberry yield, quality and growth. Austral. J. Exp. Agric., 43:105-111.

Linnemannstons, T., A. Ancay and A.C. Baroffio (2013). Strawberry drip irrigation in plastic tunnel-effects of irrigation frequency on water use, yield and fruit quality. International Strawberry Congress, 4-6 September, Antwerp, Belgium.

Lipe, W. N. and C.V. Wendt (2008). Effect of antitranspirants on yield, grade distribution, and water use of potatoes Am. J. of Potato Res., 55 (4):203 - 209.

Lolicato, S. (2011). Sunburn Protection for Fruit - a practical manual for orchardists in northern Victoria. Department of Primary Industries, Victoria.

Miller and D.R. Keeney (1982). Methods of soil analysis. 11- chemical and microbiological properties. Soil Sci.

Morley, P. S., M. Hardgrave, M. Bradley and D. J. Pilbeam (1993). Susceptibility of sweet pepper (Capsicum annuum L.) cultivars in the calcium deficiency disorder' blossom-end rot'. In: Optimization of Plant Nutrition, 563-567.

Nakano, Y. U. (1996). The effects of kaolin clay on cuticle transpiration in tomato Acta Horticulturae $440: 41$.

Passioura, J.B. (1996). Drought tolerance in higher plants : Genetical, physiological and molecular biological analysis, Klumer Academic Publishers, Dordercht, pp.3-12

Saleh, M.M.S. and S.M. Ashry (2006). Effect of some antitranspirants on leaf mineral contents, fruit set, yield and fruit quality of Washington Noval and Succary orange trees J.A. PP.Sci. Res. 2 :486490

Santos , M. B.; P. S. Teresa andA. J. Whidden (2012) .Reducing Sprinkler Irrigation Volumes for Strawberry Transplant Establishment in Florida HortTechnology vol. 22 no. 2 224-227.

Segura, S. M., A.V. Vallejo, A.R. Godoy and H.R. Diaz (2015). Effect of kaolin application on growth , water use efficiency and leaf epidermis characteristics of physicist peruvianal seedling under Tavo irrigation regimes .J.Agr Sci Tech.vol 17 : 1585-1596.

Snedecor, G.W. and W.G. Cochran (1982). Statistical Methods $7^{\text {th }}$ Ed. $2^{\text {nd }}$ printing , Lowa State . Univ. Press, Amer., USA, pp507.

Srinivasa, N.K. (1986). The effect of antitranspirants on stomatal opening and proline and relative water contents in tomato Journal of Horticultural Science 61: 369-382.

Stefansson, A. I. Gunnarsson and N. Giroud (2007). New methods for the direct determination of dissolved inorganic, organic and total carbon in natural waters by regent - free ion chromatography and inductively coupled plasma atomic emission spectrometry. Anal. Chim. Acta. 582 (1) : 69-74.

Wang, Y.S. and G. J. Galletta (1996). Effect of silicon on strawberry plants HortScience 31: 4675.

Willmer, C. and M.D. Fricker (1996). Stomata. Chapman and Hall, London.

Yasuto, M. and E. Takahshi (1986). Effect of silicon on the growth and fruit production of strawberry plants in a solution culture. Soil Scie. Nutr. 32 (2) 321-326.

Zeng, C.Z., L.Z. Bie and Z.B. Yuan (2009). Determination of optimum irrigation water amount for drip-irrigated muskmelon (Cucumis melo L.) in plastic greenhouse. Agricultural Water Management. (96): 595-602. 
تأثير فترات الري و مضادات التتح على نمو ومحصول وجودة الفراولة تحت نظام الري بالتنقيط ـ

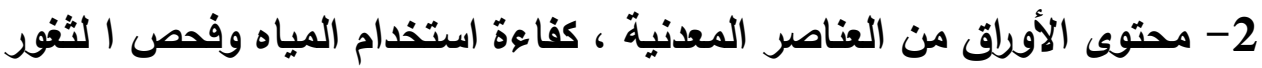
بالميكروسكوب الالكتروني.

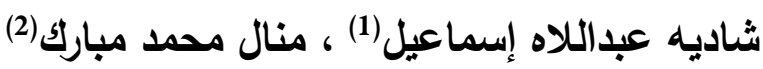

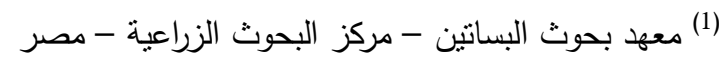

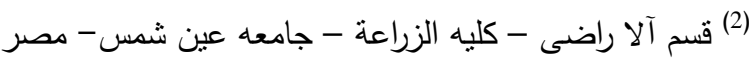

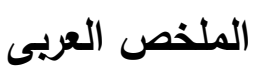
تم تتفيذ هذه التجربة خلال موسمي 2013-2014 ، 2014-2015 بمزرعة محطة بحوث القناطر - محافظه القليوبية

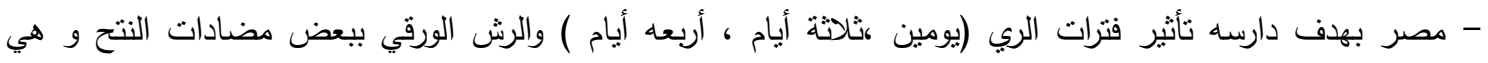
سيليكات البوتاسيوم، سيليكات الصوديوم ، كربونات الكالسيوم ، كربونات الماغنسيوم و سيليكات الالومنيوم (الكاؤلين) على الى الئ

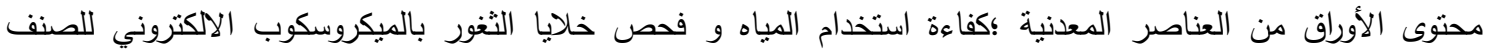

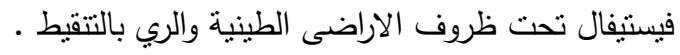

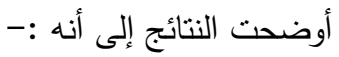

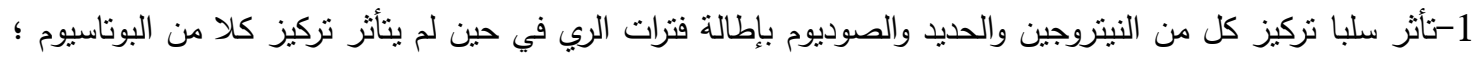
الكالسيوم؛ الزنكك و المنجنيز في موسمي الدراسة كما أدت المعامله بسليكات الصوديوم وسليكات الالومنيوم الى زياده

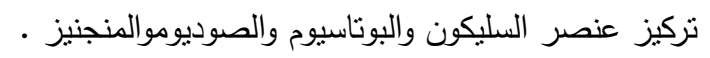

2-أدت معامله التفاعل بين الري كل ثلاث أو أربعه أيام مع الرش بأبي من الكاؤلين أو سيليكات البوتاسيوم إلي زيادة تركيز

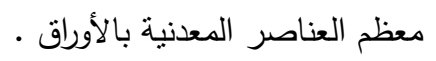

3- بالنسبة لكفاءة استخدام المياه سجلت معامله التفاعل بين الري كل أربعه أيام والرش بسيليكات الالومنيوم (الكاؤلين) أو

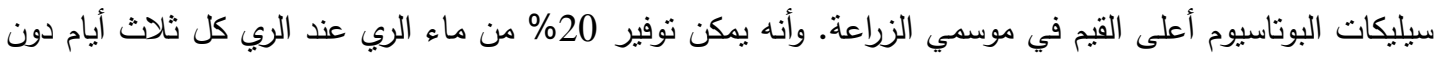

$$
\text { فرق معنوي في المحصول وذاللك باستخدام احدي مضادات النتح تحت الدراسية. }
$$

4- أظهرت نتائج فحص الميكروسكوب الالكتروني للثغور أن المعاملة بمضادات النتح قد أدت إلي الانغلاق النسبي للثغور

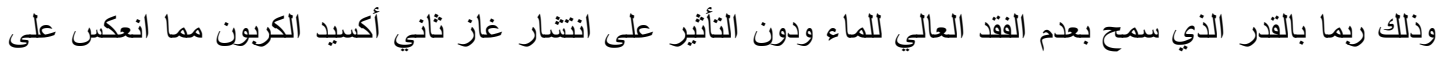
عمليه البناء الضوئي وبالثالي علي أنتاج المحصول و ذللك مقارنه بثغور النباتات الغير معامله والتي ظلت مفتوحة بقدر

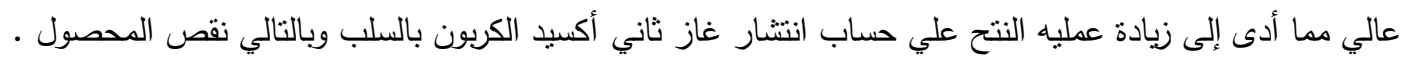

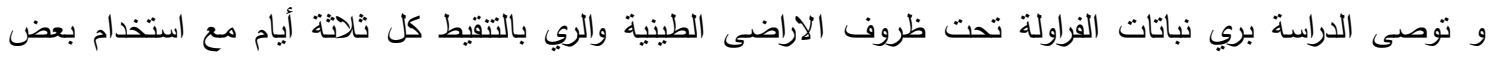

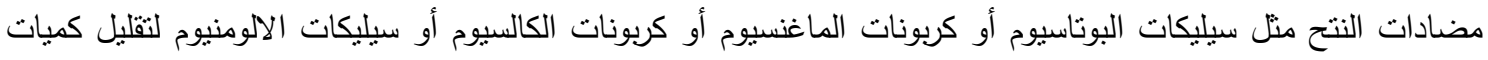
المياه المطلوبة وزيادة كفاءة استخدام المياه لمحصول الفراولة تحت ظروف محافظه القليوبية .

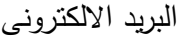

E-mail:mujareg@gmail.com
موقع المجلة

Mujareg.blogspot.com 
Cabello, M.J., M.T. Castellanos; F. Romojaro; C. Martı́nez-Madrid and F. Ribas (2009). Yield and quality of melon grown under different irrigation and nitrogen rates. Agric. Water Manage., 96:866 - 874.

Passioura, J.B. (1996). Drought and drought tolerance in higher plants : Genetical , physiological and molecular biological analysis, Klumer Academic Publishers, Dordercht . pp.3-12 . 